\title{
NMU Gene
}

National Cancer Institute

\section{Source}

National Cancer Institute. NMU Gene. NCI Thesaurus. Code C24635.

This gene plays a regulatory role in smooth muscle contraction. 